\title{
Changes in biomass and chemical composition during lecithotrophic larval development of the southern stone crab Paralomis granulosa
}

\author{
Javier A. Calcagno ${ }^{1, *}$, Sven Thatje ${ }^{2}$, Klaus Anger ${ }^{3}$, Gustavo A. Lovrich ${ }^{4}$, \\ Antje Kaffenberger ${ }^{3}$ \\ ${ }^{1}$ Universidad de Buenos Aires, Facultad de Ciencias Exactas y Naturales, Intendente Güiraldes 2160, Lab 64, $4^{\text {to }}$ Piso, Pab II, \\ Cdad Universitaria C1428EHA, Buenos Aires, Argentina \\ ${ }^{2}$ Alfred Wegener Institute for Polar and Marine Research, PO Box 120 161, 27515 Bremerhaven, Germany \\ ${ }^{3}$ Biologische Anstalt Helgoland, Stiftung Alfred Wegener Institute for Polar and Marine Research, 27498 Helgoland, Germany \\ ${ }^{4}$ Consejo Nacional de Investigaciones Científicas y Técnicas, Centro Austral de Investigaciones Científicas, CADIC, CC 92, \\ V9410BFD Ushuaia, Tierra del Fuego, Argentina
}

\begin{abstract}
Changes in biomass and elemental composition (dry mass, $\mathrm{W}_{i}$ carbon, $\mathrm{C}_{i}$ nitrogen, $\mathrm{N}_{i}$ hydrogen, H) were studied in the laboratory during complete larval and early juvenile development of the southern stone crab Paralomis granulosa (Jacquinot). At $6 \pm 0.5^{\circ} \mathrm{C}$; total larval development from hatching to metamorphosis lasted ca. $56 \mathrm{~d}$, comprising 2 demersal zoeal stages and a benthic megalopa, with mean stage durations of 5, 11 and $45 \mathrm{~d}$, respectively. All larval stages of $P$. granulosa are lecithotrophic, and first feeding and growth were consistently observed immediately after metamorphosis to the first juvenile crab stage. Regardless of presence or absence of food, W, C, N, and H decreased throughout larval development. Also the C:N mass ratio decreased significantly, from 7.2 at hatching to 4.2 at metamorphosis, indicating that a large initial lipid store remaining from the egg yolk was gradually utilised as an internal energy source. In total, about $68 \%$ of the initial quantities of $\mathrm{C}$ and $\mathrm{H}$ present at hatching, and $44 \%$ of $\mathrm{N}$ were lost during non-feeding larval development to metamorphosis. Approximately $10 \%$ of the initially present $\mathrm{C}, \mathrm{N}$ and $\mathrm{H}$ were lost with larval exuviae, half of which was lost in the megalopa stage alone. Hence, metabolic biomass degradation accounted for losses of ca. $59 \%$ in $\mathrm{C}$ and $\mathrm{H}$, but for only $33 \%$ in N. Most of the losses in $\mathrm{C}$ and $\mathrm{H}$ reflected metabolic energy consumption (primarily lipid degradation), while ca. $1 / 4$ of the losses in $\mathrm{N}$ and $2 / 3$ of those in $\mathrm{W}$ were due to larval exuviation. Complete larval lecithotrophy is based on an enhanced maternal energy investment per offspring, and on energy-saving mechanisms such as low larval locomotory activity and low exuvial losses. These traits are interpreted as bioenergetic adaptations to food-limited conditions in subantarctic regions, where a pronounced seasonality limits the period of primary production.
\end{abstract}

KEY WORDS: Lecithotrophy $\cdot$ Cold adaptation - Larval development - Subantarctic $\cdot$ Crustacea · Decapoda

\section{INTRODUCTION}

Lithodid crabs are typical inhabitants of coldtemperate subpolar and polar environments of both hemispheres (Dawson 1989, Stevens 2002), where physiological constraints associated with cold (Pörtner et al. 2000, Frederich et al. 2001), and strong food limitation due to pronounced seasonality (Knox 1994), have forced strong adaptations in life history. Lithodids contribute an important number of species to the generally impoverished decapod fauna of high latitudes (Gorny 1999), while they are of less importance in decapod communities of warm-water and tropical regions (Anger et al. 2003 and references therein). The 
success in cold water environments also contributes to lithodids being typical inhabitants of the deep sea, another large, cold and food-limited marine environment (Gorny 1999, Zaklan 2002). Larval development in some lithodids is known to succeed over a wide temperature range (e.g. Paralomis granulosa, Anger et al. 2003). Moreover, lecithotrophic development may have evolved as a key adaptation allowing for occupation of an ecological niche in food-limited cold environments, where decapod crustaceans generally cannot compete with other arthropod groups such as peracarid crustaceans (Arntz et al. 1997).

The stone crab Paralomis granulosa inhabits the cold temperate waters of the Magellan region, including the Falkland Islands/Islas Malvinas (Campodonico \& Guzman 1981, Hoggarth 1993, Lovrich 1997). Most of the commercial exploitation of $P$. granulosa is restricted to the Strait of Magellan and the Beagle Channel, where this species recently replaced the traditional king crab fishery following the collapse of local stocks of Lithodes santolla (Campodonico \& Guzman 1981, Lovrich 1997).

Most knowledge on the biology of lithodids has arisen from interest in the fishery, and as a consequence, an extensive literature is available on growth, feeding, taxonomy and fisheries management of lithodids in general (for references see Dawson 1989, Lovrich 1997).

Campodonico \& Guzman (1981) carried out preliminary studies on the early larval development of Paralomis granulosa, describing the morphology of the 2 zoeal stages and the megalopa. Comoglio \& Vinuesa (1991) studied the larval development under different food conditions, but all larvae died in the Zoea II stage. Recently, larval and early juvenile morphology of $P$. granulosa was studied in more detail by McLaughlin et al. (2003), and first information on ontogenetic changes in the bioenergetics of larval and early juvenile stages of this species was provided by Kattner et al. (2003). In contrast to morphology, no information is available on ontogenetic changes in bioenergetics of larval and early juvenile stages of this species.

A food-independent mode of larval development is known from other subpolar lithodid species (Anger 1996, Shirley \& Zhou 1997, Lovrich et al. 2003), suggesting that lecithotrophy may be an adaptation to planktonic food-limitation in high latitudes. In the present study, we therefore analysed the role of food availability for larval and early juvenile development in Paralomis granulosa, comparing changes in dry mass and organic carbon, nitrogen, and hydrogen of fed and unfed larvae. This information may prove useful for future culturing of larval and juvenile subantarctic lithodids for the purpose of re-populating collapsing natural stocks in the subantarctic Magellan region (cf. Lovrich 1997).

\section{MATERIALS AND METHODS}

Capture and maintenance of ovigerous females. Ovigerous Paralomis granulosa were caught in April 2000 from ca. 15 to $30 \mathrm{~m}$ depths in the Beagle Channel (54 53.8' S, 68 $17.0^{\prime} \mathrm{W}$ ) using commercial fishery traps. The crabs were transferred to the local institute Centro Austral de Investigaciones Científicas (CADIC, Ushuaia, Argentina) and subsequently kept in aquaria at $6 \pm 0.5^{\circ} \mathrm{C}$ for ca. 1 mo. During the next month the crabs were taken to Bremerhaven (Germany) aboard the German RV 'PFS Polarstern', and subsequently taken to the marine biological laboratory on Helgoland, Germany. During transport, filtered seawater was changed 3 times per week and food (squid) was given 2 times per week. The females were maintained individually in flow-through aquaria with at least 201 of water at constant $6 \pm 0.5^{\circ} \mathrm{C}, 32 \%$ salinity, and an artificial 12:12 h light:dark cycle.

Rearing of larvae and juveniles. Freshly hatched larvae were collected every morning in sieves (300 $\mu \mathrm{m}$ mesh size) receiving the overflow from the aquaria. The sieves were cleaned every evening to ensure that larval age did not vary by more than $12 \mathrm{~h}$.

Actively swimming larvae were randomly selected and transferred to $100 \mathrm{ml}$ individual bowls with seawater. One group of larvae was reared without food, while another was provided with freshly hatched Artemia sp. nauplii (Argent Chemical Laboratories).

The larvae were checked daily for deaths or moults, and shed exuviae were sampled for later analyses of lost biomass. Water was changed every $2 \mathrm{~d}$ and, where applicable, food was supplied.

The larvae invariably passed through 2 zoeal stages and 1 megalopa, evidenced by the appearance of exuviae and morphological changes. The Zoea II differs from the first stage in the presence of small but conspicuous pleopod buds (Campodonico \& Guzman 1981, McLaughlin et al. 2003). When the benthic megalopa was reached, a piece of nylon mesh $(200 \mu \mathrm{m}$ mesh size) was placed in each bowl as an artificial substrate to facilitate settlement and metamorphosis.

Elemental and biochemical analyses. Samples for determinations of dry mass (W) and elemental composition $\left(\mathrm{C}_{i} \mathrm{~N}_{i} \mathrm{H}_{i}\right.$ with $\mathrm{n}=5$ replicates each; 1 ind. replicate $^{-1}$ ) were taken immediately after hatching (Day 0) and at variable intervals during later development (see Table 1). All larvae sampled for elemental analyses originated from the same female. Exuviae were sampled from each larval stage to quantify biomass losses during successive moults. Since a minimum of $0.2 \mu \mathrm{g}$ dry mass is needed for each elemental analysis, 20 exuviae of larvae originating from various females per replicate sample (with $\mathrm{n}=5$ replicates) were pooled. 
Table 1. Paralomis granulosa. Changes in dry mass (W) and contents of carbon (C), nitrogen (N) and hydrogen (H) (all in \% of W; mean $\pm \mathrm{SD}$ ) during larval development in presence or absence of food (Artemia sp.) and during growth of the first juvenile crab stage (always fed); age given in days within each stage (a) and after hatching (b)

\begin{tabular}{|c|c|c|c|c|c|c|c|c|c|c|}
\hline \multirow[t]{2}{*}{ Stage } & \multicolumn{2}{|c|}{ Age } & \multicolumn{2}{|c|}{$\mathrm{W}\left(\mu \mathrm{g}\right.$ ind..$\left.^{-1}\right)$} & \multicolumn{2}{|c|}{$\mathrm{C}(\%$ of $\mathrm{W})$} & \multicolumn{2}{|c|}{$\mathrm{N}(\%$ of $\mathrm{W})$} & \multicolumn{2}{|c|}{$\mathrm{H}(\%$ of $\mathrm{W})$} \\
\hline & (a) & (b) & With & Without & With & Without & With & Without & With & Without \\
\hline \multirow{2}{*}{ Zoea I } & 0 & 0 & $985 \pm 109$ & $985 \pm 109$ & $54.8 \pm 1.7$ & $54.8 \pm 1.7$ & $7.7 \pm 0.4$ & $7.7 \pm 0.4$ & $8.2 \pm 0.3$ & $8.2 \pm 0.3$ \\
\hline & 4 & 4 & $928 \pm 57$ & $964 \pm 101$ & $53.3 \pm 0.8$ & $51.9 \pm 1.8$ & $7.8 \pm 0.2$ & $7.7 \pm 0.2$ & $8.2 \pm 0.1$ & $7.8 \pm 0.3$ \\
\hline \multirow[t]{2}{*}{ Zoea II } & 0 & 5 & $906 \pm 88$ & $861 \pm 113$ & $52.7 \pm 0.7$ & $50.7 \pm 2.2$ & $7.6 \pm 0.2$ & $7.9 \pm 0.4$ & $7.9 \pm 0.1$ & $7.6 \pm 0.4$ \\
\hline & 10 & 14 & $715 \pm 95$ & $809 \pm 83$ & $48.1 \pm 1.5$ & $48.9 \pm 1.3$ & $8.6 \pm 0.6$ & $8.2 \pm 0.2$ & $7.1 \pm 0.3$ & $7.3 \pm 0.2$ \\
\hline \multirow[t]{4}{*}{ Megalopa } & 0 & 15 & $847 \pm 113$ & $752 \pm 85$ & $48.3 \pm 1.7$ & $49.3 \pm 1.4$ & $7.9 \pm 0.5$ & $8.3 \pm 0.4$ & $7.2 \pm 0.3$ & $7.3 \pm 0.2$ \\
\hline & 15 & 30 & $829 \pm 43$ & $891 \pm 43$ & $40.9 \pm 0.5$ & $39.8 \pm 2.4$ & $7.1 \pm 0.1$ & $7.0 \pm 0.3$ & $6.0 \pm 0.1$ & $5.9 \pm 0.3$ \\
\hline & 30 & 43 & $765 \pm 103$ & $794 \pm 85$ & $38.7 \pm 1.0$ & $33.7 \pm 0.6$ & $6.8 \pm 0.2$ & $7.0 \pm 0.1$ & $5.5 \pm 0.5$ & $4.8 \pm 0.1$ \\
\hline & 36 & 50 & $703 \pm 61$ & $726 \pm 51$ & $35.1 \pm 1.6$ & $34.2 \pm 1.4$ & $7.7 \pm 0.4$ & $7.4 \pm 0.3$ & $5.1 \pm 0.3$ & $5.0 \pm 0.2$ \\
\hline \multirow[t]{11}{*}{ Crab I } & 0 & 53 & $552 \pm 69$ & $492 \pm 83$ & $37.5 \pm 1.8$ & $36.0 \pm 3.2$ & $8.8 \pm 0.4$ & $8.6 \pm 0.6$ & $5.5 \pm 0.3$ & $5.2 \pm 0.6$ \\
\hline & 2 & 55 & $744 \pm 73$ & & $31.3 \pm 2.0$ & & $6.6 \pm 0.1$ & & $4.3 \pm 0.4$ & \\
\hline & 5 & 58 & $1049 \pm 162$ & & $26.2 \pm 0.6$ & & $5.1 \pm 0.2$ & & $3.4 \pm 0.2$ & \\
\hline & 10 & 63 & $1201 \pm 422$ & & $24.3 \pm 0.8$ & & $4.5 \pm 0.4$ & & $3.1 \pm 0.2$ & \\
\hline & 15 & 68 & $1545 \pm 156$ & & $24.5 \pm 0.8$ & & $4.3 \pm 0.1$ & & $3.1 \pm 0.2$ & \\
\hline & 20 & 73 & $1446 \pm 227$ & & $26.6 \pm 1.0$ & & $4.7 \pm 0.0$ & & $3.4 \pm 0.2$ & \\
\hline & 25 & 78 & $1580 \pm 178$ & & $28.6 \pm 0.9$ & & $5.0 \pm 0.2$ & & $3.8 \pm 0.1$ & \\
\hline & 30 & 83 & $1583 \pm 407$ & & $28.5 \pm 1.7$ & & $5.2 \pm 0.1$ & & & \\
\hline & 35 & 88 & $1771 \pm 285$ & & & & & & & \\
\hline & 40 & 93 & $1782 \pm 276$ & & & & & & & \\
\hline & 45 & 98 & $1576 \pm 314$ & & $30.6 \pm 1.0$ & & $5.9 \pm 0.2$ & & $4 \pm 0.2$ & \\
\hline Crab II & 0 & 99 & $955 \pm 131$ & & $39.3 \pm 2.7$ & & $8.9 \pm 0.8$ & & $6 \pm 0.5$ & \\
\hline
\end{tabular}

Dry mass was measured to the nearest $0.1 \mu \mathrm{g}$ on an autobalance (Mettler, UMT 2). C, N and H contents of larvae and juvenile crabs were analysed as described by Anger \& Harms (1990): short rinsing in distilled water, blotting on lint-free Kleenex paper for optical use, freezing at $-18^{\circ} \mathrm{C}$, vacuum-drying at $<10^{-2} \mathrm{mb}$, weighing and combusting at $1020^{\circ} \mathrm{C}$ in a Fison (Carlo Erba) 1108 Elemental Analyser.

Statistical treatments. For both treatments (with and without Artemia), changes in biomass parameters (W, C, N, H) were described and compared with linear regressions in relation to larval age (Sokal \& Rohlf 1995). The data were previously log+1-transformed to achieve normality and homoscedasticity (tested with Kolmogorov-Smirnov and Bartlett's tests, respectively) and exclude 0 values. Slope parameters of linear regressions obtained for the different treatments were compared with an ANCOVA using the F-statistic (Sokal \& Rohlf 1995). In the text, figures and tables, arithmetic mean values \pm 1 SD calculated for $\mathrm{n}=5$ replicate measurements are given.

\section{RESULTS}

\section{Larval development}

The development through the zoeal Stages I and II took on average ca. 5 and $11 \mathrm{~d}$, respectively, while the megalopa lasted ca. 45 d. Thus, total larval development from hatching to metamorphosis took ca. $61 \mathrm{~d}$. The presence or absence of food did not influence larval development duration or survival.

\section{Dry mass, \% $\mathrm{C}, \mathrm{N}, \mathrm{H}, \mathrm{C}: \mathrm{N}$ mass ratio}

W decreased continuously from hatching to metamorphosis, regardless of food availability (Table 1, Fig. 1). On Day 36 of the megalopa stage (50 d after hatching), the average $\mathrm{W}$ of both fed and unfed larvae was ca. 71 to $73 \%$ of the initial value measured at hatching. The losses of $\mathrm{C}$ and $\mathrm{H}$ were in general proportionally higher than those of total W (Table 1). As a consequence, the $\mathrm{C}$ fraction of $\mathrm{W}$ decreased from 55 to $35 \%$, and that of $\mathrm{H}$ from 8 to $5 \%$. In contrast, the percentage of $\mathrm{N}$ remained stable, indicating that it declined in approximate proportion to total W. Since C was lost at a proportionally higher rate than $\mathrm{N}$, the $\mathrm{C}: \mathrm{N}$ mass ratio decreased significantly during larval development, indicating a decreasing lipid:protein ratio (Fig. 2). The highest C:N values were thus measured at hatching $(7.2 \pm 0.4)$, while the lowest figures occurred shortly before metamorphosis $(4.2 \pm 0.2$ to $4.3 \pm 0.2$, in unfed and fed individuals, respectively). These patterns indicate a significant extent of lipid utilisation throughout the course of larval development, regardless of the presence or absence of food. 


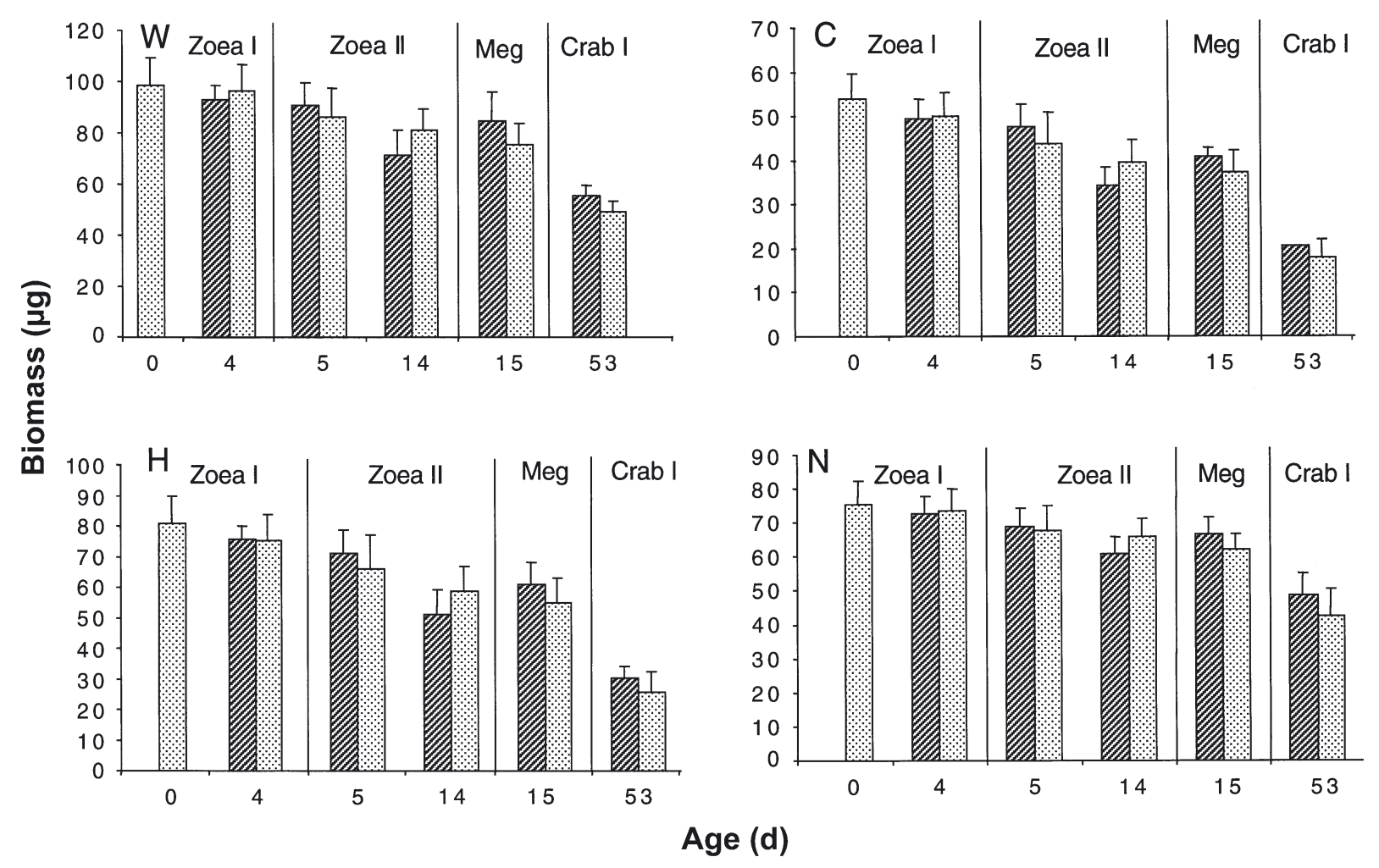

Fig. 1. Paralomis granulosa. Changes in dry mass (W) and contents of carbon $(\mathrm{C})$, nitrogen $(\mathrm{N})$ and hydrogen $(\mathrm{H})\left(\mathrm{all}\right.$ in $\mu \mathrm{g}$ ind.$^{-1}$; mean $\pm \mathrm{SD}$ ) during larval development from hatching to metamorphosis in presence or absence of food (Artemia sp.). Striped bars = with Artemia; dotted bars = without Artemia

First feeding was consistently observed immediately after metamorphosis to the first juvenile crab stage. This behavioural change was reflected in a rapidly increasing dry mass during the first ca. 35 to $40 \mathrm{~d}$ of the first juvenile instar (Table 1, Fig. 3). Thereafter, W remained almost constant. Due to the loss of a comparably heavy exuvia (see 'Exuvial losses' below), the freshly moulted Crab II instar showed a conspicuously lower dry mass than the late Crab I (Fig. 3).

The \% $\mathrm{C}, \mathrm{N}$ and $\mathrm{H}$ values decreased rapidly during the initial period (postmoult) of the Crab I instar (Table 1). Since the absolute (per ind.) amounts of these elements increased, this indicates that total W (including the mineral fraction) increased initially faster than the organic fraction of biomass. Later during the moulting cycle, the percentage values of $\mathrm{C}, \mathrm{N}$ and $\mathrm{H}$ increased slightly or remained constant (Table 1).

The average $\mathrm{C}: \mathrm{N}$ mass ratio increased rapidly during the postmoult phase of the first juvenile stage, from an initial value of $4.2 \pm 0.3$ to a maximum of $5.7 \pm 0.1$, ca. $10 \mathrm{~d}$ after metamorphosis. This increase was followed by slightly decreasing values in premoult (Fig. 2). A much lower value $(4.4 \pm 0.1)$ was measured in the freshly moulted Crab II stage.

\section{Organic biomass $(\mathrm{C}, \mathrm{N}, \mathrm{H})$ per individual}

The absolute contents of $\mathrm{C}, \mathrm{N}$ and $\mathrm{H}\left(\mu \mathrm{g}\right.$ ind..$^{-1}$ ) are considered as measures of organic biomass. These values changed during the time of larval and early juvenile development with similar patterns as total dry mass (W; see Figs. 1 \& 3). The rates of change in $\mathrm{C}$ and $\mathrm{H}$ were higher than in $\mathrm{W}$ and $\mathrm{N}$. Comparing biomass values in a late megalopa (36 d) with those measured immediately after hatching of the Zoea I (Day 0) revealed differential utilisation of different fractions. While only ca. $28 \%$ of the W initially present, and $31 \%$ of $\mathrm{N}$, were lost during this developmental period (50 d from hatching), more than half of the $\mathrm{C}$ and $\mathrm{H}$ fractions had disappeared concomitantly (54 and $51 \%$, respectively). These losses include both the previous exuvial losses of the zoeal stages (but not yet that of the megalopa) and the metabolic degradation of organic substrates, which will be considered below.

Individual larval biomass decreased gradually. When slopes of the linear regressions of $\mathrm{N}, \mathrm{C}, \mathrm{H}$, and $\mathrm{N}$ versus time of development were compared, no measure of biomass in fed and unfed larvae differed significantly. This corroborates again our inference that all larval stages of Paralomis granulosa are fully leci- 
thotrophic (non-feeding) even in the presence of a planktonic food source.

The first juvenile crab instar, which was always fed with Artemia, showed a continuous and significant increase in W up to Day 35, whereas $\mathrm{C}, \mathrm{H}$, and $\mathrm{N}$ increased significantly until the end of the Crab I stage (Fig. 3). During the initial period (postmoult and early intermoult stages), the biomass of the Crab I stage increased on average ca. 3 times in total dry mass, and more than double its initial contents of $\mathrm{C}, \mathrm{N}$ and $\mathrm{H}$. The proportionally higher increase in $\mathrm{W}$ reflects the postmoult mineralization of the exoskeleton with inorganic constituents. Missing data in the Crab I instar (Days 35 to 40 ) resulted from lack of material (see Table 1).

\section{Exuvial losses}

Total dry mass and contents of $\mathrm{C}, \mathrm{N}$ and $\mathrm{H}$ per exuvia were generally low and similar in the zoeal stages, while significantly higher values were found in the megalopa and Crab I stages (Table 2). At the moult of metamorphosis the megalopa lost more biomass than the 2 zoeal stages combined, and the first juvenile crab lost more exuvial matter (especially $\mathrm{W}$ and $\mathrm{C}$ ) than all larval stages combined.

The percentage $\mathrm{C}, \mathrm{N}$ and $\mathrm{H}$ values (in $\%$ of $\mathrm{W}$ ) in exuviae were, in general, far below those of the whole body, while the exuvial C:N mass ratio was mostly higher than in total body mass of larvae and early juveniles (cf. Table 1). The $\mathrm{C}, \mathrm{N}$ and $\mathrm{H}$ percentages tended to decrease in successive developmental stages, while the $\mathrm{C}: \mathrm{N}$ ratio increased.

The zoeal stages produced very thin and fragile exuviae with low contents of $\mathrm{C}, \mathrm{N}$ and $\mathrm{H}$. As a consequence, they lost only 3.8 to $3.9 \%$ of premoult $\mathrm{W}$ and ca. 1.5 to $2.3 \%$ of premoult $\mathrm{C}, \mathrm{N}$ and $\mathrm{H}$. Much higher losses occurred in the megalopa, which lost $37.5 \%$ of premoult $\mathrm{W}, 8.7 \%$ of $\mathrm{N}$, and 15 to $16 \%$ of $\mathrm{C}$ and $\mathrm{H}$. Yet higher losses were observed in the first juvenile crab stage, where $40 \%$ of total premoult $\mathrm{W}$, $18 \%$ of $\mathrm{C}, 4.8 \%$ of $\mathrm{N}$, and $9 \%$ of $\mathrm{H}$ were discarded with the exuvia.

About $6 \%$ of the initial (posthatching) $\mathrm{W}$ and 4 to $5 \%$ of the initially available $\mathrm{C}, \mathrm{N}$ and $\mathrm{H}$ were lost with the exuviae of the 2 zoeal stages combined. Another $27 \%$ of initial $\mathrm{W}$ and ca. 4 to $5 \%$ of $\mathrm{C}, \mathrm{N}$ and $\mathrm{H}$ were lost with the megalopal exuvia cast at metamorphosis. Exuvial losses are much smaller than metabolic losses, except for the dry weight cast at the metamorphic moult (Fig. 4).

During lecithotrophic larval development from hatching to metamorphosis, total losses of biomass (i.e. the combined effects of exuviation and metabolism) can be estimated as the difference between initial bio-
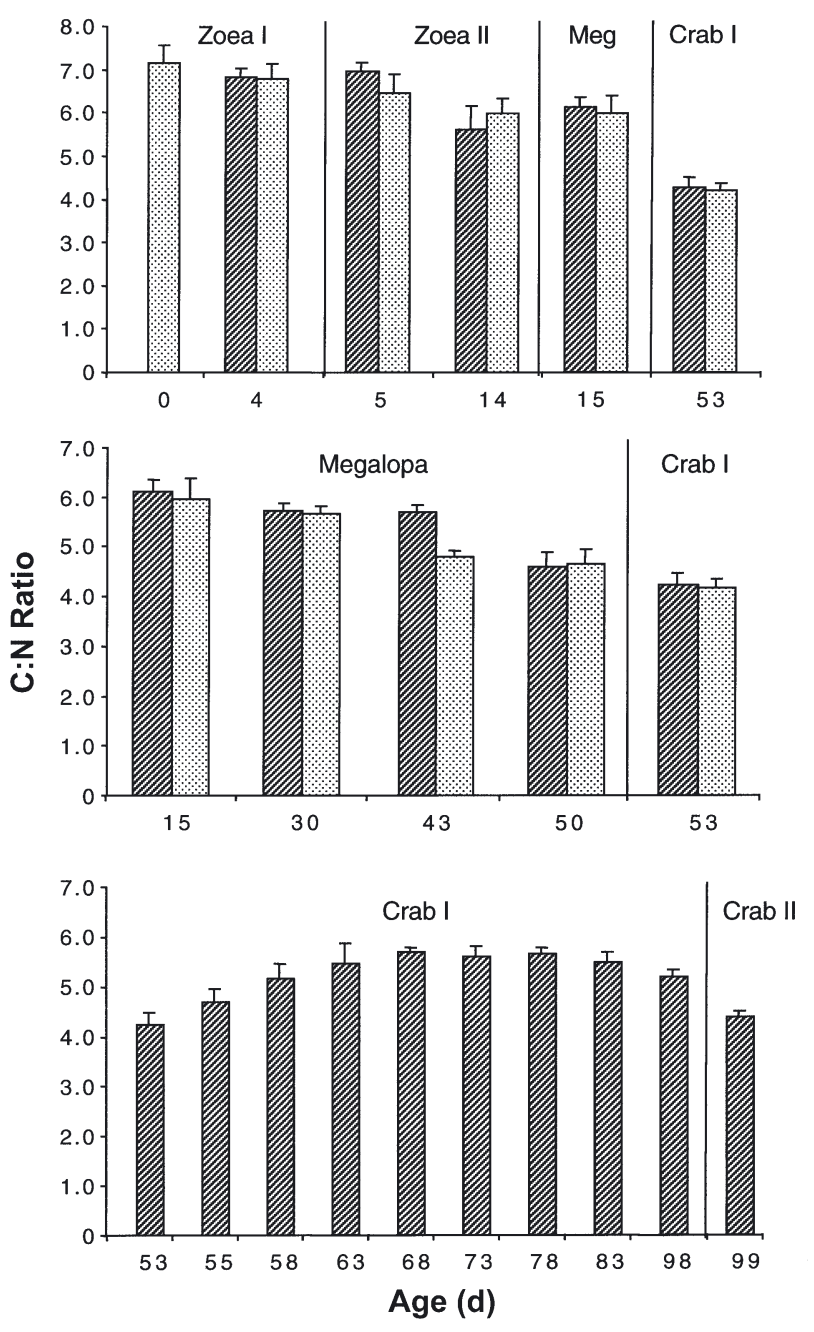

Fig. 2. Paralomis granulosa. C:N mass ratio during larval and early juvenile development. Striped bars = with Artemia; dotted bars = without Artemia

mass measured immediately after hatching (Day 0) and that of the late megalopa (Day 36, or $50 \mathrm{~d}$ after hatching; see Table 1), after subtracting the biomass of the megalopal exuvia (Table 2). In $\mathrm{W}, \mathrm{C}, \mathrm{N}$, and $\mathrm{H}$, these total losses amounted to ca. 492, 361, 34, and $55 \mu \mathrm{g}$ ind. ${ }^{-1}$, or $50,67,44$, and $69 \%$ of the initial (Day 0) values, respectively. Within these losses, the cast exuviae (all larval stages combined) accounted for ca. $2 / 3$ of $\mathrm{W}$ and $1 / 4$ of $\mathrm{N}$ lost from hatching to metamorphosis, while metabolic biomass degradation was responsible for most of the losses in $\mathrm{C}$ and $\mathrm{H}$ (Fig. 4).

\section{DISCUSSION}

The southern stone crab Paralomis granulosa shows complete lecithotrophy and a strongly abbreviated 


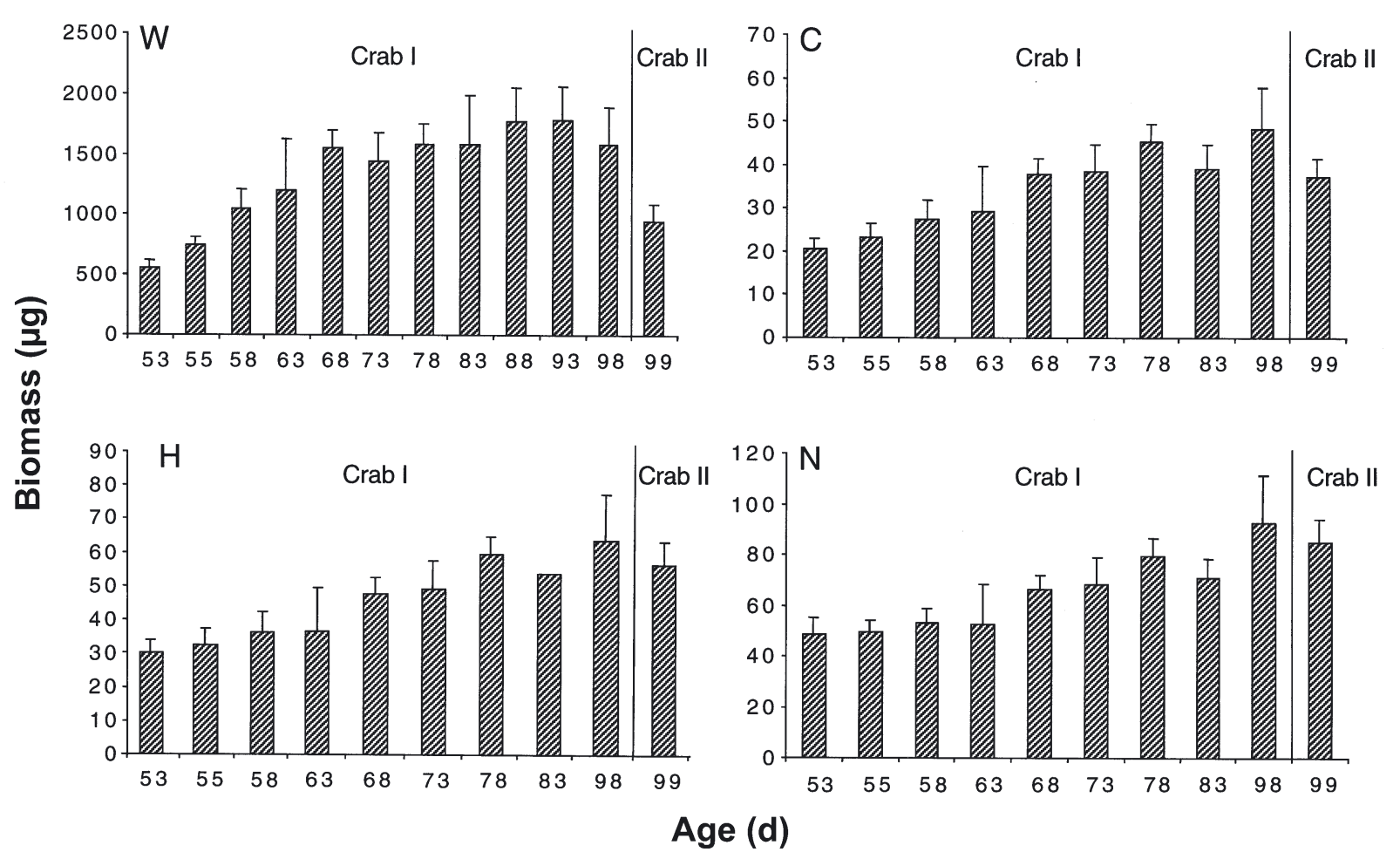

Fig. 3. Paralomis granulosa. Changes in dry mass (W) and contents of carbon $(\mathrm{C})$, nitrogen $(\mathrm{N})$ and hydrogen $(\mathrm{H})\left(\mathrm{all}\right.$ in $\mu \mathrm{g}$ ind.$^{-1}$; mean $\pm \mathrm{SD}$ ) during early juvenile development

larval development with 2 zoeal stages and a megalopa. These reproductive patterns are strikingly similar to those observed in another lithodid crab from the subantarctic Beagle Channel, the southern king crab

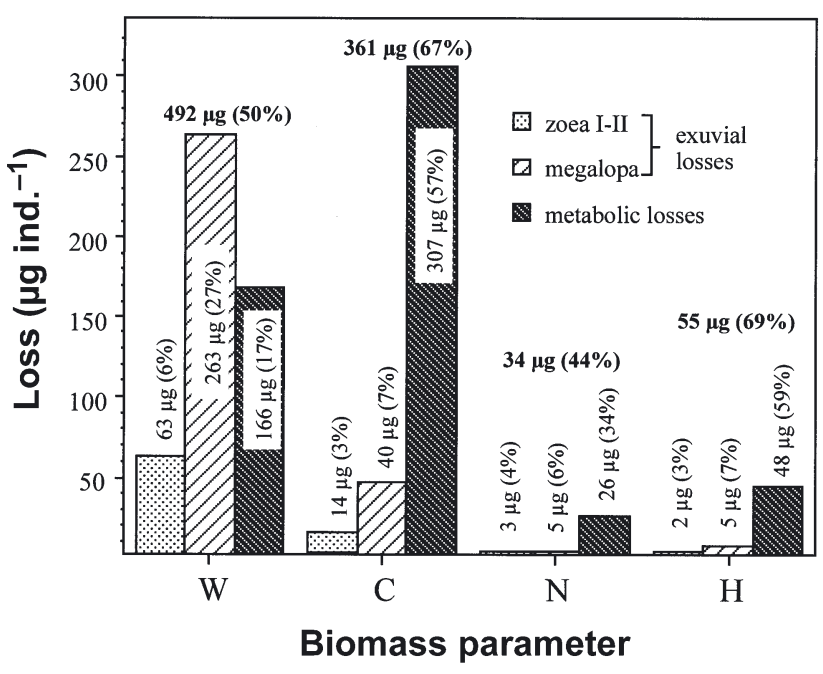

Fig. 4. Paralomis granulosa. Exuvial and metabolic losses of dry mass $(\mathrm{W})$, carbon $(\mathrm{C})$, nitrogen $(\mathrm{N})$, and hydrogen $(\mathrm{H})$ (in $\mu \mathrm{g}$ ind. ${ }^{-1} ; \%$ of initially present biomass values at hatching)
Lithodes santolla (Molina), which has 3 zoeal stages and a megalopa (Lovrich et al. 2003). Both species occur in the Magellan region, where strong seasonality in light availability and low average temperatures are typical, allowing for only a short period of primary production. In both species, hatching of larvae occurs in winter (July to September; Lovrich \& Vinuesa 1999, Thatje et al. 2003). According to larval development duration at ca. 5 to $6^{\circ} \mathrm{C}$ (average water temperature in the Beagle Channel in late winter; Lovrich 1999), metamorphosis and first food uptake of the actively feeding benthic juvenile should occur in spring (September to November), when primary production increases (see Anger et al. 2003).

Food-independent endotrophic larval development in subantarctic lithodids is based on an enhanced energy allocation to female reproduction (for recent discussion, see Anger 2001). High initial egg yolk reserves are indicated by extremely high initial $\mathrm{C}: \mathrm{N}$ ratios (in Paralomis granulosa 7.2; in Lithodes santolla 7.7, cf. Lovrich et al. 2003) allowing for degradation of lipid reserves during the larval stages (Kattner et al. 2003). Lost energy resources are replenished after metamorphosis, shown by increasing $\mathrm{C}$ : $\mathrm{N}$ ratios when first food uptake and rapid growth occur in the Crab I stage (Fig. 3; see also Lovrich et al. 2003). 
Table 2. Paralomis granulosa. Dry mass (W), contents of carbon $(\mathrm{C})$, nitrogen $(\mathrm{N})$ and hydrogen $(\mathrm{H})$, and C:N mass ratio of the exuviae of all larval stages and the first juvenile crab; mean $\pm \mathrm{SD}$

\begin{tabular}{|c|c|c|c|c|c|c|}
\hline Stage & & W & $\mathrm{C}$ & $\mathrm{N}$ & $\mathrm{H}$ & $\mathrm{C}: \mathrm{N}$ mass ratio \\
\hline Zoea I & $\begin{array}{l}\mu \mathrm{g} \text { ind. }^{-1} \\
\% \text { of } \mathrm{W}\end{array}$ & $35 \pm 5$ & $\begin{array}{r}8.4 \pm 0.7 \\
24 \pm 4.1\end{array}$ & $\begin{array}{l}1.7 \pm 0.1 \\
4.8 \pm 0.8\end{array}$ & $\begin{array}{l}1.3 \pm 0.1 \\
3.8 \pm 0.6\end{array}$ & $5 \pm 0.06$ \\
\hline Zoea II & $\begin{array}{l}\mu \mathrm{g} \text { ind. }^{-1} \\
\% \text { of } W\end{array}$ & $28 \pm 5$ & $\begin{array}{r}5.6 \pm 0.7 \\
20 \pm 2.1\end{array}$ & $\begin{array}{r}1 \pm 0.1 \\
3.5 \pm 0.4\end{array}$ & $\begin{array}{l}0.9 \pm 0.1 \\
3.1 \pm 0.2\end{array}$ & $5.7 \pm 0.04$ \\
\hline Megalopa & $\begin{array}{l}\mu \mathrm{g} \text { ind. }^{-1} \\
\% \text { of } \mathrm{W}\end{array}$ & $264 \pm 23$ & $\begin{array}{l}40 \pm 2.1 \\
15 \pm 1.1\end{array}$ & $\begin{array}{l}4.7 \pm 0.1 \\
1.8 \pm 0.16\end{array}$ & $\begin{array}{r}5.4 \pm 0.4 \\
2 \pm 0.2\end{array}$ & $8.5 \pm 0.33$ \\
\hline Crab I & $\begin{array}{c}\mu \mathrm{g} \text { ind. }^{-1} \\
\% \text { of } \mathrm{W}\end{array}$ & $623 \pm 96$ & $\begin{array}{l}86 \pm 13.3 \\
14 \pm 13.8\end{array}$ & $\begin{array}{r}4.5 \pm 0.91 \\
0.66 \pm 0.71\end{array}$ & $\begin{array}{l}5.6 \pm 1 \\
0.9 \pm 0.9\end{array}$ & $19.5 \pm 1$ \\
\hline
\end{tabular}

The production of unusually thin exuviae by the lecithotrophic larvae of $P$. granulosa suggests an energy-saving mechanism, which may be typical of non-feeding larvae. This was also observed in the lecithotrophic development of a terrestrial grapsid crab, Metopaulias depressus, and might thus indicate a general pattern in various decapod taxa with endotrophic development (Anger \& Schuh 1992; for recent discussion of the literature see Anger 1996, 2001).

We suggest that food-independent larval development may be an important life-history adaptation to limited primary production in subantarctic marine environments. This trait may partially explain the wide range of bathymetric distribution of some subantarctic lithodid species, from the shallow sublittoral to the deep sea (Lovrich \& Vinuesa 1993), where scarce planktonic food availability presumably selects against an extended planktotrophic larval development.

The overexploitation of lithodid crabs in the Magellan region has caused a collapse of Paralomis granulosa and Lithodes santolla populations, especially in the Strait of Magellan and the Beagle Channel (Lovrich 1997). Both species show low adult growth rates (Lovrich \& Vinuesa 1995) and long generation times of ca. 12 and 6 yr, respectively (Lovrich \& Vinuesa 1999). Aquaculture or stock enhancement attempts have not yet succeeded, mainly due to lack of knowledge of the early life history and suitable rearing conditions (e.g. Vinuesa et al. 1989). The long generation time may not allow economical aquaculture of lithodids alone, but polyculture in combination with shrimp or salmon farming might be feasible. Our results suggest that rearing of juvenile lithodids for re-population of natural stocks could be a relatively easy procedure, aiding a sustainable and economical local fishery. However, restocking programmes alone may not compensate for historic and recent overexploitation of king crab populations in cold subpolar waters.
Acknowledgements. We greatly appreciate the help of the crew of RV 'PFS Polarstern' during the transport of live king crabs. Special thanks are due to C. Püschel for elemental analyses. E. Heyer and R. Hottung helped in maintaining larval cultures. J.A.C. is grateful to the German Academic Exchange Service (DAAD) for funding his research visit to Helgoland. This project was funded by the International Bureau of the German Ministry of Scientific Research (BMBF, project no. ARG 99/002), and the Argentine Secretaría Nacional para la Tecnología, Ciencia e Inovación Productiva (SETCIP). We greatly acknowledge the helpful comments by 4 anonymous reviewers.

\section{LITERATURE CITED}

Anger K (1996) Physiological and biochemical changes during lecithotrophic larval development and early juvenile growth in the northern stone crab, Lithodes maja (Decapoda: Anomura). Mar Biol 126:283-296

Anger K (2001) The biology of decapod crustacean larvae. Crustacean Issue 14. AA Balkema Publishers, Lisse, p 1-420

Anger K, Harms J (1990) Elemental (CHN) and proximate biochemical composition of decapod crustacean larvae. Comp Biochem Physiol 97B:69-80

Anger K, Schuh M (1992) Bioenergetics of abbreviated larval development in the bromelid crab, Metopaulias depressus (Decapoda: Grapsidae). Comp Biochem Physiol 103A:507-518

Anger K, Thatje S, Lovrich GA, Calcagno JA (2003) Larval and early juvenile development of Paralomis granulosa reared at different temperatures: tolerance of cold and food limitation in a lithodid crab from high latitudes. Mar Ecol Prog Ser 253:243-251

Arntz WE, Gutt J, Klages M (1997) Antarctic marine biodiversity: an overview. In: Battaglia B, Valencia J, Walton DWH (eds) Antarctic communities: species, structure and survival. Cambridge University Press, Cambridge, p 3-14

Campodonico I, Guzman L (1981) Larval development of Paralomis granulosa (Jaquinot) under laboratory conditions (Decapoda, Anomura, Lithodidae). Crustaceana 40: 278-285

Comoglio L, Vinuesa J (1991) Larval culture of southern king crab Lithodes santolla and false king crab Paralomis granulosa under laboratory conditions. In: Lavens $\mathrm{P}_{\mathrm{r}}$ Sorgeloos P, Jaspers E, Ollevier F (eds) LARVI '91, fish and crustacean larviculture symposium. European Aquaculture Society, Spec Publ 15, Gent, p 349-351

Dawson EW (1989) King crabs of the world (Crustacea: Lithodidae) and their fisheries: a comprehensive bibliography. 
Miscellaneous Publication 101. New Zealand Oceanography Institute, Division of Water Sciences, Wellington

Frederich M, Sartoris FJ, Pörtner HO (2001) Distribution patterns of decapod crustaceans in polar areas: a result of magnesium regulation? Polar Biol 24:719-723

Gorny M (1999) On the biogeography and ecology of the Southern Ocean decapod fauna. Sci Mar 63(Suppl 1): 367-382

Hoggarth DD (1993) The life history of the lithodid crab, Paralomis granulosa, in the Falkland Islands. ICES J Mar Sci 50:405-424

Kattner G, Graeve M, Calcagno JA, Lovrich GA, Thatje S, Anger K (2003) Lipid, fatty acid and protein utilization during lecithotrophic larval development of Lithodes santolla (Molina) and Paralomis granulosa (Jacquinot). J Exp Mar Biol Ecol 292:61-74

Knox GA (1994) The biology of the Southern Ocean. Cambridge University Press, Cambridge

Lovrich GA (1997) La pesquería mixta de las centollas Lithodes santolla y Paralomis granulosa (Anomura: Lithodidae) en Tierra del Fuego, Argentina. Invest Mar (Valparaíso) 25:41-57

Lovrich GA (1999) Seasonality of larvae of Brachyura and Anomura (Crustacea Decapoda) in the Beagle Channel, Argentina. Sci Mar 63(Suppl 1):347-354

Lovrich GA, Vinuesa JH (1993) Reproductive biology of the false southern king crab (Paralomis granulosa, Lithodidae) in the Beagle Channel, Argentina. Fish Bull 91:664-675

Lovrich GA, Vinuesa JH (1995) Growth of immature false southern king crab, Paralomis granulosa (Anomura, Lithodidae), in the Beagle Channel, Argentina. Sci Mar 59:87-94

Lovrich GA, Vinuesa JH (1999) Reproductive potential of the lithodids Lithodes santolla and Paralomis granulosa (Anomura, Decapoda) in the Beagle Channel, Argentina. Sci Mar 63(Suppl 1):355-360

Lovrich GA, Thatje S, Calcagno JA, Anger K, Kaffenberger A (2003) Changes in biomass and chemical composition during lecithotrophic larval development of the Southern

Editorial responsibility: Otto Kinne (Editor), Oldendorf/Luhe, Germany king crab, Lithodes santolla (Molina). J Exp Mar Biol Ecol 288:65-79

McLaughlin PA, Anger K, Kaffenberger A, Lovrich GA (2003) Larval and early juvenile development in Paralomis granulosa (Jacquinot) (Decapoda: Anomura: Paguroidea: Lithodidae), with emphasis on abdominal changes in megalopal and crab stages. J Nat Hist 37:1433-1452

Pörtner HO, Van Dijk PLM, Hardewig I, Sommer A (2000) Levels of metabolic cold adaption: tradeoffs in eurythermal and stenothermal ectotherms. In: Davison W, Howard Williams C (eds) Antarctic ecosystems: models for wider ecological understanding. Coxton Press, Christchurch, p 109-122

Shirley TC, Zhou S (1997) Lecithotrophic development of the golden king crab Lithodes aequispinus (Anomura: Lithodidae). J Crustac Biol 17:207-216

Sokal RR, Rohlf FJ (1995) Biometry: the principles and practice of statistics in biological research. WH Freeman, New York, p 1-887

Stevens BG (2002) Checklist of Alaskan crabs. In: Paul AJ, Dawe EG, Elner R, Jamieson GS and 5 others (eds) Crabs in cold water regions: biology, management, and economics. University of Alaska Sea Grant College Program AK-SG-02-01, Fairbanks, AK, p 5-8

Thatje S, Calcagno JA, Lovrich GA, Sartoris FJ, Anger K (2003) Extended hatching periods in the subantarctic lithodid crabs Lithodes santolla and Paralomis granulosa (Crustacea: Decapoda). Helgol Mar Res 57:110-113

Vinuesa JH, Lovrich GA, Comoglio LI (1989) Temperaturesalinity effects on the larval development in false southern king crab, Paralomis granulosa (Crustacea, Anomura). Thalassas 7:53-57

Zaklan SD (2002) Review of the family Lithodidae (Crustacea: Anomura: Paguroidea): distribution, biology, and fisheries. In: Paul AJ, Dawe EG, Elner R, Jamieson GS and 5 others (eds) Crabs in cold water regions: biology, management, and economics. University of Alaska Sea Grant College Program AK-SG-02-01, Fairbanks, AK, p 751-845

Submitted: September 4, 2002; Accepted: May 8, 2003 Proofs received from author(s): July 16, 2003 